\title{
Hubungan Konsep Diri dan Kecerdasan Emosional dengan Stres Kerja pada Pendeta Geraja Batak Karo Prostestan di Wilayah Langkat
}

\section{The Relationship of Self Concept and Emotional Intelliegence with Work Stress of Reverence Gereja Batak Karo Protestan in Langkat}

\author{
Elly Enjelita*, Nefi Darmayanti \& Azhar Aziz \\ Program Studi Magister Psikologi, Program Pascasarjana,Universitas Medan Area
}

\begin{abstract}
Abstrak
Penelitian ini bertujuan untuk mengetahui hubungan konsep diri dan kecerdasan emosional dengan stres kerja pada pendeta Gereja Batak Karo Protestan (GBKP) di wilyah Langkat. Populasi penelitian ini adalah pendeta GBKP yang melayani di Wilayah Langkat yang terdiri dari dua klasis, yaitu: Klasis Binjai Langkat dan Klasis Kuala Langkat, sebanyak 42 orang dengan teknik total sampling. Data yang dikumpulkan dengan menggunakan angket. Data yang terkumpul dianalisis dengan menggunakan teknik deskriptip, uji asumsi, dan uji hipotesis. Berdasarkan analisis yang dilakukan, diperoleh hasil : 1) Ada hubungan negatif signifikan antara konsep diri dengan stres kerja, R2 = 0,112 berarti konsep diri memiliki kontribusi sebesar 11,2 \% dalam menjelaskan stres kerja, hal ini berarti semakin negatif konsep diri maka semakin tinggi stres kerja, 2) Ada hubungan negatif signifikan antara kecerdasan emosional dengan stres kerja, R2 = 0,278 berarti kecerdasan emosional memiliki kontribusi sebesar 27,8 \% dalam menjelaskan stres kerja, hal ini berarti semakin rendah kecerdasan emosional maka semakin tinggi stres kerja, 3) Ada hubungan negatif signifikan antara konsep diri dan kecerdasan emosional secara bersama-sama dengan stres kerja, Angka R2 = 0,306 berarti variabel konsep diri dan variabel kecerdasan emosional memberikan kontribusi sebesar 30,6 \% dalam menjelaskan stres kerja.

Kata Kunci: Konsep Diri, Kecerdasan Emosional, Stres Kerja
\end{abstract}

\section{Abstract}

This study was aims to determine the relationship of self concept and emotional intelliegence with work stress of reverence Gereja Batak Karo Protestan (GBKP) in Langkat area. The population of this study are reverences that serve the churches GBKP in Langkat area, consisting of: Klasis Binjai Langkat and Klasis Kuala Langkat as many as 42 people with total sampling tecnique. Data collected by questionnaire. The data collected were analyzed using desciptive tecnique, nalaysis erquirements test, and hypothesis test. Based on the anaysis performed, the result obtained:1) There is a significant negative relationship between self-concept with work stress, value $R 2=0,112$ means self concept given $11,2 \%$ contribution to explain work stress, this means the more negative self concept then the higher the work stress. 2) There is a significant negative relationship between the emotional intelliegence with work stress, $R 2=$ 0,278 means emotional intelliegence given $27,8 \%$ contribution to explain work stress, this means lower the emotional intelliegence then the higher the work stress. 3) There is a significant negative relationship between the self concept and emotional intelliegence together with work stress, value $R 2=0,306$ means self concept and emotional intelliegence given $30,6 \%$ contribution to explain work stress, this means negative self concept and lower the emotional intelliegence then the higher the work stress.

Keywords: Self Concept, Emotional Intelliegence and Work Stress

How to Cite: Enjelita, E., Nefi, D., Azhar, A. (2019). Hubungan Persepsi Siswa terhadap Konselor dan Sarana Prasarana BK dengan Minat Layanan Konseling di SMPN 2 Dewantara Kabupaten Aceh Utara. Tabularasa: Jurnal Ilmiah Magister Psikologi, 1(2) 2019: 123-137

*E-mail: leeniel@ymail.com

ISSN 2550-1305 (Online)

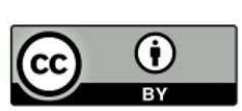




\section{PENDAHULUAN}

Kehadiran Pendeta adalah sebagai "tokoh sentral" atau "public figure" di kalangan jemaat. Berbicara tentang peranan pendeta sebagai pemimpin jemaat dan masyarakat pada masa kini maka banyak harapan jemaat dan masyarakat kepada Pendeta sebagai pemimpin. Pendeta harus memainkan banyak peranan di tengah-tengah gereja dan masyarakat, agar kebutuhan jemaat dan masyarakat banyak dapat terpenuhi melalui kehadiran pendeta di dalam tugas dan pelayanan, dimana pendeta di tempatkan melayani.

Tugas utama pendeta sebagai pemimpin menurut pandangan Gintings (2002) adalah mengurus jiwa manusia yang terkait ke dalam kehidupan seutuhnya. Penggembalaan ini disebut juga sebagai Pastoral Care, berarti gembala / pendeta yang mau memperdulikan, mau mengurus jiwa orang lain. Ini dilakukan berdasarkan kebenaran Alkitab yang tertulis dalam Injil Matius 6:33, Tetapi carilah dulu kerajaan Allah dan kebenaranNya, maka semuanya itu akan ditambahkan kepadamu. Pendeta sebagai pemimpin jemaat dan masyarakat sudah selayaknya seorang yang mempunyai kepribadian kebapaan atau keibuan bagi pendeta perempuan. Kepribadian ini menyangkut kewibawaan, dan tidak diukur dengan keadaan fisik seseorang.

Peranan pendeta dalam kehidupan sehari-hari harus diwujudnyatakan dan dimulai dari dirinya/keluarga pendeta, adalah hal yang tidak boleh ditawar-tawar. Intinya kehidupan pendeta seperti etalase toko yang dilihat secara jernih dan terang benderang oleh jemaat. Atau seperti ikan yang hidup di aquarium yang ditonton banyak orang. Akibatnya mau tidak mau dari pendeta dituntut kematangan dan kesiapan seluruh anggota keluarga menjadi teladan bagi jemaat (Simanjuntak, 2014).

Sama dengan setiap individu lain bagi pendeta kepuasan kerja merupakan salah satu faktor yang sangat penting untuk mendapatkan hasil kerja yang optimal. Keberhasilan seorang pendeta dalam pelayanan tidak melulu karena faktor spiritualitas. Juga tidak hanya bergantung pada iman atau kerohanian individu semata, tapi berkaitan erat juga dengan kepribadiannya. Jika kepribadian pendeta tidak matang, maka pendeta itu bisa menjadi penghambat rekan kerja yang lainnya, atau menjadi penghambat semangat individu yang melayani dalam kelompok. Saat individu bekerja dalam komunitas sosial atau keagamaan, dia tidak selalu (mampu) hanya melihat Tuhan. Dia juga memandang manusia dengan siapa dia bekerjasama (Simanjuntak, 2014). Ketika individu merasakan kepuasan dalam bekerja tentunya dia akan berupaya semaksimal mungkin dengan segenap kemampuan yang dimilikinya untuk menyelesaikan tugas pekerjaannya dan dengan demikian produktivitas dan hasil kerja kerja individu akan meningkat secara optimal.

Kondisi dan semangat kerja pendeta yang menurun akan mengakibatkan mengalami frustasi berkepanjangan dan stres yang kerja tinggi. Tingkat stres yang tinggi dari pendeta mungkin disertai dengan kemarahan, kecemasan, depresi, gelisah, cepat marah, tegang dan bosan. Sebuah studi menemukan bahwa dampak stres yang paling kuat adalah pada tindakan agresif, seperti sabotase, agresi antar pribadi, permusuhan, dan keluhan. Jenis masalah psikologis akibat stres tersebut relevan dengan kinerja yang buruk, penghargaan diri yang rendah, benci pada pengawasan, ketidakmampuan dalam berkonsentrasi dan membuat keputusan, dan ketidakpuasan kerja (Lutans, 2006). Dampak dari stres yang 
dialami pendeta ini akan membuat pendeta tersebut tidak mampu lagi maksimal dalam melaksanakan tugasnya dalam mengurusi jiwa-jiwa jemaat, kurang mampu memimpin dan kurang berintegritas, visi dan misi yang tidak jelas, kurang rasa percaya diri dan merasa rendah diri, cenderung merasa tidak disukai orang lain, pesimis untuk mengembangkan diri dan berprestasi sehingga tidak kreatif dalam menciptakan program, suka mengeluh, kurang mampu menguasai diri sehingga emosi tidak terkontrol, kurang mampu memberi solusi bagi persoalan yang dihadapi jemaat dan tidak lagi menjadi panutan di dalam keluarga dan bagi jemaat.

Banyak dilema yang bisa kita dengar dari kehidupan pribadi dan keluarga pendeta, kehidupan yang penuh dinamika, tantangan, kesulitan, termasuk kekurangan finansial. Tapi yang sangat menekan perasaan adalah jemaat terlalu banyak menuntut pendeta. Waktu mereka yang dikuras habis untuk mengurus jemaat, sampai waktu dengan keluarga merupakan sisa-sisa waktu saja. Kesalahan pendeta sering dicari-cari, seolah-olah pendeta tidak boleh salah. Terpeleset sedikit saja langsung menjadi "trending topic" bagi jemaat (Simanjuntak, 2014).

Penulis melihat fakta-fakta lain yang terjadi dalam kehidupan pendeta adalah tuntutan pekerjaan yang kronis seperti jadwal kerja yang ketat, beban kerja yang terlalu tinggi, tuntutan kerja yang tinggi, tugas-tugas yang menekan, harus siap setiap saat, kemampuan diri yang kurang, dan konflik interpersonal, maka hal ini dapat menyebabkan stres. Keadaan yang menekan secara tidak langsung adalah suatu konsekuensi yang berhubungan dengan kejadian-kejadian di sekitar lingkungan kerja sehingga mengakibatkan suatu ketidakseimbangan antara tuntutan kerja dan kemampuan kerja individu baik secara fisik maupun psikologis. Persoalan-persoalan yang terjadi dalam lingkungan kerja seperti suasana kerja, ketidaknyamanan dalam bekerja, konflik dengan rekan kerja, perselisihan, maupun ketidakmampuan individu menyesuaikan diri dengan pekerjaan dan lingkungan kerjanya berpeluang besar terhadap munculnya stres kerja. Sehingga penulis melihat bahwa pendeta mempunyai kecenderungan untuk mengalami stres.

Pada dasarnya stres merupakan hasil interaksi dan transaksi antara seorang individu dengan lingkungannya. Segala macam bentuk stres pada dasarnya disebabkan oleh kekurangmengertian manusia akan keterbatasan-keterbatasannya sendiri. Ketidakmampuan untuk melawan keterbatasan inilah yang akan menimbulkan frustasi, konflik, gelisah dan ras bersalah yang merupakan tipe-tipe dasar stres. Akibat-akibat stres terhadap seseorang dapat bermacam-macam dan hal ini tergantung pada kekuatan konsep dirinya yang akhirnya menentukan besar kecilnya toleransi orang tersebut terhadap stres (Anoraga, 2009). Jadi sebenarnta menurut Anoraga ada dua faktor utama yang berkaitan langsung dengan stres, yaitu perubahan dalam lingkungan dan daru diri manusianya.

Menurut Wijono (2011) aspek-aspek yang menjadi sumber dari stres adalah aspek pekerjaan itu sendiri dan di luar pekerjaan itu sendiri. a) Aspek di dalam (internal) pekerjaan itu sendiri, meliputi: faktor-faktor yang berkaitan dengan pekerjaan seorang individu, stres peran, peluang partisipasi, tanggung jawab dan faktor-faktor organisasi. b) Aspek di luar (eksternal) pekerjaan itu sendiri, meliputi : perubahan struktur kehidupan, 
dukungan sosial, Locus of Control, tipe A \& B, harga diri, fleksibilitas / kaku dan kemampuan.

Collins (1989) mengemukakan tiga penyebab stres: a. Masyarakat, b.Peristiwaperistiwa tertentu dalam kehidupan, c. Dari diri sendiri. Sejalan dengan faktor ini Stein (2003) mengemukakan diri sendiri merupakan fondasi tempat dibangunnya hampir semua unsur kecerdasan emosional, langkah awal yang penting untuk menjelajahi dan memahami diri dan keinginan untuk berubah. Wijono (2011) mengemukakan faktor lain yang dapat menimbulkan stres kerja : 1. Sikap terhadap pekerjaan, 2. Jika seseorang menganggap bahwa pekerjaannnya adalah sesuatu yang "kurang bermakna dan mempunyai nilai" bagi dirinya, maka dia akan mengalami perasaan tidak puas. 3. Keadaan lingkungan kerja

Setiap pendeta juga mempunyai pengalaman stres yang berbeda-beda, secara umum Collins (1989) mengemukakan lima faktor tekanan hidup yang dialami oleh hampir setiap pendeta: a) Isolasi dari masyarakat, b) Tuntutan yang berlebihan, c) Masalah keuangan, d) Masalah administrasi dan e) Tekanan mental

Dari uraian diatas penulis menyimpulkan faktor pemicu stres adalah isolasi dari masyarakat, tuntutan yang berlebihan, masalah administrasi, masalah keuangan, dan tekanan mental (dari diri sendiri). Ini sering sekali berdampak pada pendeta dan keluarganya sering sekali merasa gagal dan bersalah besar apabila mereka tidak dapat menjadi model seperti yang diinginkan oleh jemaatnya. Kemudian masalah kemarahan, setiap individu bisa marah dan marah tidak selalu buruk. Tetapi kemarahan seringkali menyebabkan luapan emosi yang tidak terkendali, kata-kata yang kasar, menyakitkan, kritik dan rusaknya hubungan dengan sesame (Hamdani, et al., 2015; Zuraida, et al., 2015; Harahap, et al., 2014; Syarifah \& Darmayanti, 2010; Siregar, 2012).

Burn (dalam Ruben, 2014) mengemukakan tiga aspek dalam konsep diri: a) Aspek Fisik, b) Aspek Sosial dan c) Aspek Psikologi. Goleman (2016) mengatakan bahwa kecerdasan emosional adalah kemampuan lebih yang dimiliki seseorang dalam memotivasi diri sendiri, dan bertahanan menghadapi frustasi, mengendalikan dorongan hati dan tidak melebih-lebihkan kesenangan; mengatur suasana hati dan menjaga agar beban stres tidak melumpuhkan kemampuan berpikir; berempati dan berdoa. Dengan kecerdasan emosional tersebut seseorang dapat menempatkan emosinya pada porsi yang tepat, memilah kepuasan dan mengatur suasana hati.

Goleman (2016) mengungkapkan lima wilayah yang mengungkapkan komponen utama kecerdasan emosional yang dapat menjadi pedoman bagi individu untuk mencapai kesuksesan dalam kehidupan sehari-hari, yaitu : a) Mengenali emosi diri, b) Mengelola emosi, c) Memotivasi diri, d) Mengenali emosi orang lain, dan e) Membina hubungan dengan orang lain.

Konsep diri berhubungan erat dengan sukses atau gagal dalam karir hidup. Fabella (1993) mengemukakan sebuah hasil dari para peneliti dan dan pekerja klinik telah mengetahui untuk bertahun-tahun bahwa dalam suatu situasi dimana individu menilai rendah dirinya, akan merasa dirinya tanpa bantuan serta menderita berbagai kegagalan, adapun anggapan seperti ini sesungguhnya membuat dia benar-benar gagal dalam situasi tersebut. 
Wijono (2011) mengemukakan ada individu yang merasa mempunyai kemampuan untuk mengatasi stres kerja tetapi ada juga individu yang tidak mempunyai kemampuan mengatasi stres kerjanya. Hal tersebut sangat tergantung dari konsep diri yang dimiliki oleh individu yang berbeda-beda pada setiap individu. Harga diri merupakan cara penerimaan seseorang dan usaha untuk melakukan evaluasi terhadap diri sendiri atau disebut sebagai konsep diri. Jika seseorang mempunyai konsep diri positif, maka ia mempunyai harga diri tinggi sehingga ia dapat mengembangkan diri dalam kondisi, situasi atau peristiwa yang mengganggu, menekan atau mengancam dirinya, akibatnya ia mengalami stres kerja yang rendah. Sebaliknya, jika ia mempunyai harga diri yang rendah dalam menghadapi kondisi, situasi atau peristiwa yang mengganggu, menekan atau mengancam dalam pekerjaannya, maka ia akan mengalami stres kerja yang tinggi karena rasa percaya dirinya juga rendah.

Menurut Agustinus (2014) yang menyebabkan para pendeta perlu membangun konsep dirinya dengan baik dan benar adalah karena: (1) Pendeta adalah manusia baru yang ada dalam proses pertumbuhan dan perubahan menuju keserupaan seperti Kristus. Dalam perjalanan menuju keserupaan itulah, seorang pendeta perlu memiliki pengenalan diri yang baik dan benar sehingga dia tahu sejauh mana ia telah berubah dan bertumbuh dalam hidupnya. (2) Tugas pelayanan pendeta mencakup tugas dan tanggung jawab untuk mebina relasi dengan sesamanya. Dalam membina relasi tidak dapat dilepaskan dari pengenalan dan penerimaan dirinya sendiri. (3) Pendeta yang memiliki konsep diri yang keliru berpotensi menghadapi problem-problem pribadi yang menghalanginya dalam pelaksannaan tugas dan tanggung jawabnya.

Goleman (2016) mendefenisikan kecerdasan emosional sebagai kapasitas untuk mengenali perasaan diri sendiri dan orang lain, untuk memotivasi diri dan untuk mengelola emosi diri sendiri dalam hubungannya dengan orang lain. Stein (2003) menjelaskan kecerdasan emosional sangat diperlukan dalam mengatasi stres sebagai kemampuan menghadapi peristiwa yang tidak menyenangkan dan situasi yang penuh tekanan tanpa menjadi berantakan, dengan efektif, optimis dan mampu menangani dengan tenang dan memegang kendali. Inti dari kecerdasan emosional adalah kemampuan seseorang dalam mengelola dan mengekspresikan emosi sesuai dengan kondisi yang terjadi, berupa kesadaran emosi, bagaimana mengungkapkan emosi secara tepat, memotivasi diri, memahami orang lain dan menjalin hubungan dengan orang secara harmonis (Tarigan, 2018; Siregar, 2018; Nainggolan, et al., 2017; Hamdani, et al., 2015; Zuraida, et al., 2015).

Bachman (dalam Stein, 2003) mencermati keterkaitan konsep kesadaran akan diri dengan kecerdasan emosional memungkinkan individu memiliki sikap yang mandiri, tidak ragu-ragu untuk mengungkapkan kemampuan dengan efektif, mampu bekerja mencapai sasaran dengan cara mengelola waktu, mengolah informasi, dan meningkatkan kemampuan berkomunikasi dan bernegosiasi, serta memiliki optimis dan kebahagiaan, yang menciptakan suasana hati yang stabil sehingga individu dapat mengatasi stres, penolakan, frustasi, dan kekecewaan dalam pekerjaan.

Dalam upaya pendekatan kontekstual terhadap kebutuhan Gereja Batak Karo Protestan (GBKP), penulis tertarik untuk mengadakan penelitian yang berjudul: 
"Hubungan Konsep Diri Dan Kecerdasan Emosional Dengan Stres Kerja Pada Pendeta Gereja Batak Karo Protestan (GBKP) Di Wilayah Langkat”. Hipotesis dalam penelitian ini adalah ada hubungan antara konsep diri dan kecerdasan emosional dengan stres kerja pada pendeta Gereja Batak Karo Protestan (GBKP) Di Wilayah Langkat.

Penelitian ini menitikberatkan pada tiga aspek, yaitu: konsep diri, kecerdasan emosional dan stres kerja. Secara terperinci, ketiga aspek tersebut dijelaskan sebagai berikut:

Stres kerja adalah reaksi individu yang berwujud emosi, fisiologis dan pikiran terhadap kondisi, situasi atau peristiwa yang mengancam dan memberi tekanan terhadap individu dalam pekerjaannya. Reaksi individu atas tuntutan terhadap dirinya dari indikator yang dikemukakan Collins (1989), yaitu: Isolasi dari masyarakat, tuntutan yang berlebihan, masalah administrasi, masalah keuangan dan tekanan mental. Semakin tinggi skor yang diperoleh maka semakin tinggi stres kerja. Sebaliknya semakin rendah skor maka semakin rendah pula stres kerjanya.

Konsep diri yang dimaksud dalam penelitian ini adalah pandangan inidividu tentang dirinya yang meliputi kemampuan yang dimiliki, perasaan yang dialami, kondisi fisik yang terbentuk dari pengalaman masa lalu dan interaksi dengan orang lain. Semakin tinggi skor yang diperoleh maka semakin positif konsep dirinya, sebaliknya semakin rendah skor yang diperoleh maka semakin negatif konsep dirinya.

Kecerdasan emosional adalah serangkaian kecakapan yang dimiliki oleh individu untuk memotivasi dirinya sendiri dan mengarahkan emosinya dengan tepat dan efektif atas perasaan individu itu sendiri dan terhadap tekanan dari luar dirinya. Semakin tinggi skor yang diperoleh maka semakin tinggi tingkat kecerdasan emosionalnya. Sebaliknya semakin rendah skor yang diperoleh maka semakin rendah pula kecerdasan emosionalnya.

\section{METODE PENELITIAN}

Dalam penelitian ini terdapat dua variabel bebas $(\mathrm{X} 1, \mathrm{X} 2)$ dan satu variabel terikat (Y). Variabel Independen X1 adalah konsep diri, X2 adalah Kecerdasan emosional. Variabel Dependen Y adalah Stres Kerja.

Pada penelitian ini peneliti akan melakukan penelitian populasi karena jumlah populasinya terhingga dan subjeknya tidak terlalu banyak. Populasi penelitian ini adalah seluruh Pendeta Gereja Batak Karo Protestan (GBKP) yang sedang melayani di gerejagereja GBKP di wilayah Langkat, yang terdiri dari dua klasis, yaitu Klasis Binjai Langkat yang terdiri dari 21 orang, di 21 wilayah desa / kota dan Klasis Kuala Langkat, yang terdiri dari 21 orang, di 21 wilayah desa / kota.

Ditinjau dari wilayah sumber data, maka penulis menentukan teknik sampling dalam penelitian ini adalah total sampling dengan pertimbangan populasi sumber data terhingga dan subjeknya tidak terlalu banyak. Jumlah pendeta GBKP yang terdaftar di wilayah Langkat sebanyak 42 orang.

Instrumen yang digunakan dalam penelitian ini adalah angket. Angket atau kuesioner (Questionnaires) adalah sejumlah pertanyaan tertulis yang digunakan untuk memperoleh informasi dari responden dalam arti laporan tentang pribadinya, atau hal- 
hal yang ia ketahui. Adapun alasan penggunaan angket sebagai alat pengumpul data adalah: Tidak memerlukan hadirnya peneliti, dapat dibagikan secara serentak kepada banyak responden, dapat dijawab oleh responden menurut kecepatannya masing-masing, dan menurut waktu senggang responden, dapat dibuat anonim sehingga responden bebas, jujur, dan tidak malu-malu menjawab dan dapat dibuat terstandar sehingga bagi semua responden dapat diberi pertanyaan yang benar-benar sama.

Metode penelitian yang akan dipakai disini adalah dengan menggunakan metode Skala Likert. Suryabrata (2005) mengatakan bahwa metode Skala Likert sebenarnya bernama metode Summated Ratings. Tetapi karena modelnya pertama kali diusulkan oleh Rensis Likert, maka model ini lalu terkenal dengan metode Skala Likert.

Dalam menganalis data yang berasal dari angket bergradasi atau berperingkat 1 sampai 4, peneliti menyimpulkan makna alternatif sebagai berikut: 1) "Sangat Setuju", "Sangat Sering", "Sangat Banyak", menunjukkan gradasi paling tinggi, untuk kondisi tersebut diberi nilai 4. 2) "Setuju”, "Sering”, "Banyak", menunjukkan peringkat yang lebih rendah dibandingkan dengan yang ditambah kata "Sangat", kondisi ini diberi nilai 3. 3)“Kurang Setuju”, "Jarang”, "Sedikit”, karena diberada dibawah "Setuju” diberi nilai 2, 4) "Tidak Setuju”, "Sangat Jarang”, "Sedikit Sekali”, berada di gradasi paling bawah dan diberi nilai 1.

Data yang diperoleh dari masing-masing variabel ditabulasikan dengan menggunakan tabel distribusi frekuensi. Kemudian enelitian dilakukan dalam tiga tahap, yaitu : tahap persiapan, tahap pengumpulan data, dan tahap analisis data. Kemudian dilakukan uji validitas untuk melihat sejauh mana ketepatan dan kecermatan suatu instrumen pengukuran melakukan fungsi ukurnya (Azwar, 2009). Kemudian uji reliabilitas menunjuk pada satu pengertian bahwa suatu instrumen cukup dapat dipercaya untuk digunakan sebagai alat pengumpul data karena instrumen tersebut sudah baik. Apabila datanya memang benar sesuai dengan kenyataannya, maka beberapa kali pun diambil, tetap akan sama. Reliabel artinya, dapat dipercaya, jadi dapat diandalkan (Arikunto,2013).

Data yang diperoleh dari subjek melalui skala ukur ditranformasikan ke dalam angka-angka menjadi data kuantitatif, sehingga data tersebut dapat dianalisis dengan pendekatan statistik. Analisis data kuantitatif pada penelitian ini dan uji hipotesis dengan menggunakan Analisis Regresi Ganda (multiple regression), yaitu suatu perluasan dari teknik regresi apabila terdapat lebih dari satu variabel bebas untuk mengadakan prediksi terhadap variabel terikat (Arikunto, 2013). Prediktor pertama (Variabel bebas $1=\mathrm{X} 1$ ) adalah konsep diri dan prediktor kedua (Variabel bebas $2=\mathrm{X} 2$ ) adalah kecerdasan emosional, sedangkan yang menjadi kriterium (Variabel terikat) adalah stres kerja pendeta. Kedua variabel bebas ini akan diuji secara bersamaan, sehingga dapat dilihat hubungannya terhadap variabel terikat.

\section{HASIL DAN PEMBAHASAN}

Skala Konsep Diri terdiri dari 30 pernyataan yang terbagi dalam 3 aspek yang mencakup aspek Fisik, Sosial, dan Psikis. Hasil analisis butir menunjukkan bahwa terdapat 1 pernyataan yang gugur, dengan koefisien daya beda jauh lebih kecil dari 0,3 , yaitu item 
nomor 13. Sehingga item yang valid ada 29 item dengan indeks daya beda yang bergerak mulai dari 0,305 sampai 0,653 dengan $\mathrm{p}<0,05$. Setelah selesai pengujian validitas butir, kemudian dilanjutkan dengan analisis reliabilitas dengan menggunakan pendekatan Alpha Cronbach ditemukan bahwa indeks reliabilitas skala konsep diri adalah 0,788 dengan $\mathrm{p}<0,05$. Dengan demikian dapat dikatakan bahwa skala konsep diri ini cukup andal dalam mengungkap aspek-aspek konsep diri pada pendeta GBKP di wilayah Langkat.

Skala Kecerdasan Emosional terdiri dari 30 pernyataan yang terbagi dalam 5 aspek yang mencakup aspek mengenal emosi/ kesadaran diri, mengelola emosi/menangani perasaan, memotivasi diri sendiri, mengenali emosi orang lain/empati, dan membina hubungan dengan orang lain/keterampilan mengelola emosi orang lain. Hasil analisis item menunjukkan bahwa terdapat 3 pernyataan yang gugur, dengan koefisien daya beda jauh lebih kecil dari 0,3, yaitu item nomor 6, 19, dan 26. Dengan demikian dalam skala kecerdasan emosional ini terdapat 27 pernyataan yang bisa digunakan dalam pengambilan data penelitian dengan indeks daya beda yang bergerak mulai dari 0,312 sampai 0,698 dengan $p<0,05$. Selanjutnya dari hasil uji reliabilitas dengan menggunakan pendekatan Alpha Cronbach diketahui bahwa skala kecerdasan emosional ini memiliki koefisien reliabilitas sebesar 0,762. Dengan demikian dapat dikatakan bahwa skala kecerdasan emosional ini andal untuk mengungkap kecerdasan emosional pada pendeta GBKP di wilayah Langkat.

Skala Stres Kerja terdiri dari 30 pernyataan yang terbagi dalam 5 aspek, yang mencakup aspek (1) Isolasi dari masyarakat, (2) Tuntutan yang berlebihan, (3) Masalah administrasi, (4) Masalah keuangan dan (5) Tekanan mental. Hasil analisis item menunjukkan bahwa terdapat 11 item yang gugur, dengan koefisien daya beda jauh lebih kecil dari 0,3, yaitu item nomor 1, 3, 9, 10, 14, 15, 17, 22, 23, 25 dan 30. Dengan demikian dalam skala stres kerja ini terdapat 19 item yang bisa digunakan dalam pengambilan data penelitian dengan indeks daya beda yang bergerak mulai dari 0,321 sampai 0,611 dengan $\mathrm{p}<0,05$. Selanjutnya dari hasil uji reliabilitas dengan menggunakan pendekatan Alpha Cronbach diketahui bahwa skala stres kerja ini memiliki koefisien reliabilitas sebesar 0,729; dengan demikian dapat dikatakan bahwa skala stres kerja ini andal untuk mengungkap tanggapan pendeta GBKP di wilayah Langkat terhadap stres kerja.

Analisis data yang dilakukan untuk penelitian ini adalah menggunakan analisis regresi untuk mengetahui seberapa besar kemampuan prediksi kedua variabel bebas (konsep diri dan kecerdasan emosional) terhadap variabel tergantung (stres kerja). Menurut Hadi (2000) analisis regresi digunakan untuk mengetahui seberapa besar daya prediksi satu variabel bebas (X) atau lebih dengan sebuah variabel terikat (Y). Sebelum dilakukan analisis data, terlebih dahulu dilakukan uji asumsi yang meliputi normalitas sebaran dan uji linearitas hubungan antara variabel bebas dan variabel tergantung. Keseluruhan teknik analisis data menggunakan SPSS versi 18.

Dalam penelitian ini, uji normalitas dilakukan dengan menggunakan analisis statistik dan metode uji Kolmogorov-Smirnov. Kaidah yang digunakan untuk megetahui normalitas sebaran data adalah jika $\mathrm{p}>0.05$ maka sebaran dikatakan normal, sebaliknya jika p $<0.05$ maka sebarannya tidak normal (Hadi, 2000). 
Tabel 1

Rangkuman Hasil Uji Normalitas

\begin{tabular}{cccc}
\hline Variabel & $\begin{array}{c}\text { Kolmogorov } \\
\text {-Smirnov Z }\end{array}$ & $\mathrm{P}$ & Keterangan \\
\hline Konsep diri & 1,208 & 0,108 & Normal \\
\hline $\begin{array}{c}\text { Kecerdasan } \\
\text { emosional }\end{array}$ & 0,942 & 0,338 & Normal \\
\hline Stres kerja & 1,066 & 0,206 & Normal \\
\hline Variabel & $\begin{array}{c}\text { Kolmogorov } \\
\text {-Smirnov Z }\end{array}$ & $\mathrm{P}$ & Keterangan \\
\hline
\end{tabular}

Dari tabel 1 diketahui sebaran data ketiga variabel penelitian bersifat normal, sehingga uji regresi dapat dilakukan. Uji asumsi linieritas dilakukan untuk mengetahui linieritas hubungan antara variabel bebas dengan variabel terikat. Uji linieritas dapat pula untuk mengetahui taraf penyimpangan dari linieritas hubungan tersebut. Adapun kaidah yang digunakan dalam uji linieritas hubungan adalah bila nilai linierity $\mathrm{p}<0.05$ maka hubungan dinyatakan linier.

Tabel 2

Uji Lineritas Hubungan

\begin{tabular}{cccc}
\hline Variabel & $\mathrm{F}$ & $\mathrm{p}$ & Ket \\
\hline $\begin{array}{c}\text { Konsep diri - } \\
\text { stres kerja }\end{array}$ & 7,208 & 0,004 & Linier \\
\hline $\begin{array}{c}\text { Kecerdasan } \\
\text { emosional - }\end{array}$ & 21,702 & 0,000 & Linier \\
stres kerja & & & \\
\hline
\end{tabular}

Pada tabel 2 di atas didapatkan hasil bahwa: Hasil uji asumsi linieritas antara variabel konsep diri dengan stres kerja mempunyai nilai linearity $F=7,208$ dan $p=0.04$ yang $<0.05$ yang berarti hubungannya dinyatakan linier. Hasil uji linieritas pada variabel kecerdasan emosional dengan stres kerja diperoleh nilai linearity $F=21,702$ dan $p=0,00$ yang $<0.05$. Hal ini menunjukkan bahwa hubungan kedua variabel tersebut linier. Dengan didapatkan hubungen linear ini, maka uji hipotesis dengan regresi linear dapat dilanjutkan.

Uji hipotesis diarahkan untuk menguji ketiga hipotesis yang diajukan dalam penelitian ini; Hipotesa pertama dalam penelitian ini berbunyi ada hubungan negatif antara konsep diri dengan stres kerja pada pendeta GBKP di wilayah Langkat. Asumsinya bahwa semakin rendah konsep diri maka semakin tinggi stres kerja. Kebenaran hipotesa pertama ini diperoleh melalui proses uji kolerasi dengan menggunakan Pearson Product Moment untuk mendapatkan besar dan arah hubungan antara kedua variabel tersebut. Serta menggunakan uji regresi antara variabel konsep diri dan variabel stres kerja untuk mendapatkan koefisien determinasi guna mendapatkan besarnya kontribusi variabel konsep diri dalam menjelaskan stres kerja. Rangkuman hasil perhitungan dapat dilihat sebagai berikut:

Tabel 3

Hasil Regresi Linier Antara Konsep Diri Dengan Stres Kerja

\begin{tabular}{cccc}
\hline RX1.Y & R2 & P & Keterangan \\
\hline$-0,335$ & 0,112 & 0,004 & Signifikan \\
\hline
\end{tabular}


Analisa tabel diatas adalah sebagai berikut, Besar hubungan antara variabel konsep diri dengan stres kerja (rxiy) sebesar 0,335 menunjukkan hubungan yang cukup kuat diantara keduanya. Arah hubungan yang negatif (tanda negatif pada angka 0,335) menunjukkan bahwa semakin rendah konsep diri akan akan membuat stres kerja semakin tinggi, demikian pula sebaliknya. Angka $\mathrm{R}^{2}$ sebesar 0,112 disebut sebagai koefisien determinasi, dalam hal ini berarti konsep diri memiliki kontribusi sebesar 11,2 \% dalam menjelaskan stres kerja. Sementara sisanya dipengaruhi oleh variabel lain. Tingkat signifikansi koefisien korelasi satu sisi dari output (diukur dari probabilitas p) menghasilkan angka 0,004. Oleh karena probabilitas $\mathrm{p}<0,05$ berarti korelasinya bersifat signifikan.

Hipotesa kedua dalam penelitian ini berbunyi: ada hubungan negatif antara kecerdasan emosional dengan stres kerja pada pendeta GBKP di wilayah Langkat. Asumsinya bahwa semakin rendah kecerdasan emosional maka akan semakin tinggi stres kerja. Kebenaran hipotesa kedua ini diperoleh melalui proses uji korelasi dengan menggunakan dengan menggunakan Pearson Product Moment untuk mendapatkan besar dan arah hubungan antara kedua variabel tersebut. Serta menggunakan uji regresi antara variabel kecerdasan emosional dan variabel stres kerja untuk mendapatkan koefisien determinasi guna mendapatkan besarnya kontribusi variabel kecerdasan emosional dalam menjelaskan stres kerja. Rangkuman hasil perhitungan dapat dilihat sebagai berikut:

Tabel 4

Hasil Regresi Linier antara Kecerdasan Emosional dengan Stres Kerja

\begin{tabular}{cccc}
\hline RX1.Y & R2 & P & Keterangan \\
\hline$-0,527$ & 0,278 & 0,000 & Signifikan \\
\hline
\end{tabular}

Analisa tabel diatas adalah sebagai berikut: Besar hubungan antara variabel kecerdasan emosional dengan stres kerja (rxiy) sebesar - 0,527 menunjukkan hubungan yang cukup kuat diantara keduanya. Arah hubungan yang negatif (tanda negatif pada angka 0,527) menunjukkan bahwa semakin rendah kecerdasan emosional akan akan membuat stres kerja semakin tinggi, demikian pula sebaliknya. Angka $\mathrm{R}^{2}$ sebesar 0,278 disebut sebagai koefisien determinasi, dalam hal ini berarti kecerdasan emosional memiliki kontribusi sebesar 27,8 \% dalam menjelaskan stres kerja. Sementara sisanya dipengaruhi oleh variabel lain. Tingkat signifikansi koefisien korelasi satu sisi dari output (diukur dari probabilitas $\mathrm{p}$ ) menghasilkan angka 0,000. Oleh karena probabilitas $\mathrm{p}<0,05$ berarti korelasinya bersifat signifikan.

Hipotesa ketiga dalam penelitian ini berbunyi: ada hubungan negatif antara konsep diri dan kecerdasan emosional dengan stres kerja pada pendeta GBKP di wilayah Langkat. Asumsinya bahwa semakin rendah konsep diri dan kecerdasan emosional maka akan semakin tinggi stres kerja. Kebenaran hipotesa ketiga ini diperoleh melalui proses uji regresi ganda antara variabel konsep diri dan variabel kecerdasan emosional. Hasil perhitungan uji regresi dapat dilihat sebagai berikut: 
Tabel 5

Hasil Regresi Linier antara Kecerdasan Emosional dengan Stres Kerja

\begin{tabular}{ccccc}
\hline Variabel & $\mathrm{R}$ & $\mathrm{R} 2$ & $\mathrm{P}$ & Keterangan \\
\hline $\mathrm{X} 1, \mathrm{X} 2-\mathrm{Y}$ & 0,553 & 0,306 & 0,01 & Signifikan \\
\hline
\end{tabular}

Berdasarkan hasil analisis yang menggunakan analisis Regresi Berganda, diketahui bahwa terdapat hubungan yang signifikan antara konsep diri dan kecerdasan emosional dengan stres kerja. Hal ini ditunjukkan dengan nilai koefisien Freg = 8,605 dan sig. 0,01. Analisa tabel diatas adalah sebagai berikut: Besar hubungan antara variabel konsep diri dan variabel kecerdasan emosional dengan stres kerja (rxiy) sebesar 0,553 menunjukkan hubungan yang cukup kuat. Angka $\mathrm{R}^{2}$ sebesar 0,306 disebut koefisien determinasi, dalam hal ini berarti variabel konsep diri dan variabel kecerdasan emosional memberikan kontribusi sebesar 30,6 \% dalam menjelaskan stres kerja, sisanya dipengaruhi oleh variabel lain. Tingkat signifikansi koefisien korelasi satu sisi dari output (diukur dari probabilitas p) menghasilkan angka 0,01. Oleh karena probabilitas $p<0,05$ berarti korelasinya bersifat signifikan.

Berdasarkan hasil perhitungan mean Hipotetik diperoleh nilai t untuk masingmasing variabel adalah : nilai mean hipotetiknya adalah $\{(29 \times 1)+(29 \times 4)\}: 2=72,5$. Untuk variabel kecerdasan emosional, nilai mean hipotetiknya adalah $\{(27 \times 1)+(27 \times 4)\}$ : $2=67,5$. Kemudian untuk variabel stres kerja nilai mean hipotetiknya adalah $=\{(19 \times 1)+$ $(19 \times 4)\}: 2=47,5$.

Berdasarkan hasil analisis data, seperti yang terlihat dari analisis uji normalitas diketahui bahwa, mean empirik variabel konsep diri adalah 60,74 . Untuk variabel kecerdasan emosi adalah 43,05 dan untuk variabel stres kerja adalah 89,05.

Untuk mengetahui kondisi konsep diri, kecerdasan emosional dan stres kerja pada pendeta GBKP di wilayah Langkat, maka perlu dibandingkan antara mean / nilai rata-rata empirik dengan mean / nilai rata-rata hipotetik dengan memperhatikan besarnya bilangan SD dari masing-masing variabel. Untuk variabel konsep diri nilai SD nya adalah 10,555, untuk variabel kecerdasan emosional nilai SD nya adalah 17,212, dan untuk variabel stres kerja nilai SD nya adalah 25,906. Dari besarnya bilangan SD tersebut, maka untuk variabel konsep diri, apabila mean / nilai rata-rata hipotetik <, dimana selisihnya melebihi bilangan satu SD, maka dinyatakan bahwa konsep diri tergolong tinggi dan bisa kita sebut konsep diri yang positif dan apabila mean / nilai rata-rata hipotetik >, maka konsep diri tergolong rendah dan bisa kita katakan negatif.

Tabel 4

Hasil Perhitungan Mean Hipotetik Dan Mean Empirik

\begin{tabular}{ccccc}
\hline Variabel & \multicolumn{2}{c}{ SD } & \multicolumn{3}{c}{$\begin{array}{c}\text { Mean / Nilai } \\
\text { rata-rata }\end{array}$} \\
\cline { 2 - 5 } & \multicolumn{3}{c}{$\begin{array}{c}\text { Hipoteti } \\
\mathrm{k}\end{array}$} & $\begin{array}{c}\text { Empiri } \\
\mathrm{k}\end{array}$ \\
\hline Konsep diri & 10,555 & 72,5 & 60,74 & Negatif \\
\hline $\begin{array}{c}\text { Kecerdasan } \\
\text { Emosional }\end{array}$ & 7,212 & 67,5 & 43,05 & $\begin{array}{c}\text { Renda } \\
\mathrm{h}\end{array}$ \\
\hline
\end{tabular}


Elly Enjelita, Nefi Darmayanti \& Azhar Aziz, Hubungan Persepsi Siswa terhadap Konselor dan

\begin{tabular}{lllll}
\hline Stres Kerja & 25,906 & 47,5 & 89,05 & Tinggi \\
\hline
\end{tabular}

Berdasarkan perbandingan kedua nilai rata-rata di atas mean Hipotetik dan mean empirik, maka dapat dinyatakan bahwa subjek penelitian ini memiliki konsep diri yang tergolong negatif, kecerdasan emosionalnya rendah dan memiliki stres kerja yang tinggi.

Hasil penelitian menunjukkan hubungan yang negatif signifikan antara konsep diri dengan stres kerja. Hal ini ditujukkan oleh besar hubungan antara variabel konsep diri dengan stres kerja sebesar -0,335. Sementara arah hubungan negatif $p<0,04$. Menunjukkan bahwa semakin negatif konsep diri yang dimiliki oleh para pendeta semakin tinggi stres kerja yang dimilikinya. Hasil tersebut sesuai dengan yang dikemukakan Wijono (2011) bahwa ada individu yang merasa mempunyai kemampuan untuk mengatasi stres kerja tetapi ada juga individu yang tidak mempunyai kemampuan mengatasi stres kerjanya. Hal tersebut sangat tergantung dari konsep diri yang dimiliki oleh individu yang berbeda-beda pada setiap individu. Harga diri merupakan cara penerimaan seseorang dan usaha untuk melakukan evaluasi terhadap diri sendiri atau disebut sebagai konsep diri. Jika seseorang mempunyai konsep diri positif, maka ia mempunyai harga diri tinggi sehingga ia dapat mengembangkan diri dalam kondisi, situasi atau peristiwa yang mengganggu, menekan atau mengancam dirinya, akibatnya ia mengalami stres kerja yang rendah. Sebaliknya, jika ia mempunyai harga diri yang rendah dalam menghadapi kondisi, situasi atau peristiwa yang mengganggu, menekan atau mengancam dalam pekerjaannya, maka ia akan mengalami stres kerja yang tinggi karena rasa percaya dirinya juga rendah. Agustinus (2014) berpendapat yang menyebabkan para pendeta perlu membangun konsep dirinya dengan baik dan benar adalah karena: (1) Pendeta adalah manusia baru yang ada dalam proses pertumbuhan dan perubahan menuju keserupaan seperti Kristus. Dalam perjalanan menuju keserupaan itulah, seorang pendeta perlu memiliki pengenalan diri yang baik dan benar sehingga ia tahu sejauh mana ia telah berubah dan bertumbuh dalam hidupnya. (2) Tugas pelayanan pendeta mencakup tugas dan tanggung jawab untuk membina relasi dengan sesamanya. Dalam membina relasi tidak dapat dilepaskan dari pengenalan dan penerimaan dirinya sendiri. (3) Pendeta yang memiliki konsep diri yang keliru berpotensi menghadapi problem-problem pribadi yang menghalanginya dalam pelaksannaan tugas dan tanggung jawabnya. Dengan demikian konsep diri yang negatif berpengaruh terhadap peningkatan stres kerja, khususnya bagi pendeta yang memiliki pemahaman tentang konsep dirinya yang cenderung negatif tidak sebanding dengan penghargaan yang diberikan dalam jabatan rohani yang diembannya. Semakin seseorang mengenal dan memanfaatkan kekuatan sendiri, semakin bertambah pula rasa kepercayaan diri dalam melakukan antaraksi jangka panjang dan jangka pendek. Sejalan dengan teori Myers (dalam Ruben, 2014) bahwa faktor-faktor yang mempengaruhi konsep diri adalah Jenis kelamin, budaya, perbandingan sosial dan pengalaman-pengalaman akan kegagalan dan kesuksesan. Faktor-faktor ini memiliki dampak yang positif pada berbagai aspek kehidupan seseorang, seberapa baik individu mengerjakan suatu tugas, tingkat pendidikan yang ia capai, seberapa keras individu akan berusaha dan termotivasi dalam mencapai tujuannya, 
kemampuannya dalam memecahkan masalah yang rumit, kebiasaan hidup sehat, dan bahkan untuk mengatasi stres dalam pekerjaannya.

Terdapat hubungan yang negatif signifikan antara kecerdasan emosional dengan stres kerja. Hal ini ditujukkan oleh besar hubungan antara variabel kecerdasan emosional dengan stres kerja sebesar - 0,527. Sementara arah hubungan negatif $\mathrm{p}<0,000$. Menunjukkan bahwa semakin rendah kecerdasan emosional yang dimiliki oleh para pendeta semakin tinggi stres kerja yang dimilikinya. Hasil tersebut sesuai dengan yang dikemukakan oleh Goleman (2016) mendefenisikan kecerdasan emosional sebagai kapasitas untuk mengenali perasaan diri sendiri dan orang lain, untuk memotivasi diri dan untuk mengelola emosi diri sendiri dalam hubungannya dengan orang lain. Stein (2003) menjelaskan kecerdasan emosional sangat diperlukan dalam mengatasi stres sebagai kemampuan menghadapi peristiwa yang tidak menyenangkan dan situasi yang penuh tekanan tanpa menjadi berantakan, dengan efektif, optimis dan mampu menangani dengan tenang dan memegang kendali. Dengan demikian kecerdasan emosional yang rendah akan sangat berpengaruh terhadap stres kerja pendeta, khususnya bagi pendeta yang memiliki tingkat kecerdasan emosional yang rendah yang sikapnya tentu tidak sejalan dengan jabatan rohani yang diembannya. Kecerdasan emosional merupakan ketahanan menanggung stres dengan tetap tenang dan sabar, tanpa terbawa emosi dan tidak menyerah pada rasa tidak berdaya. Wade dan Tavris (2007) dalam teorinya mengemukakan faktor-faktor yang mempengaruhi kecerdasan emosional adalah kondisi tubuh manusia, pikiran / kognisi, budaya, gender dan emosi. Faktor-faktor ini yang akan mempengaruhi individu dalam mencapai kesuksesan, memecahkan masalah-masalah dalam pekerjaan dan juga ketahanan untuk menanggung stres dalam pekerjaan. Dari hasil penelitian menunjukkan

Terdapat hubungan yang negatif signifikan antara konsep diri dan kecerdasan emosional dengan stres kerja. Hal ini ditujukkan oleh ditunjukkan oleh koefisien Freg = 8,605 dan $R=0,553$ sedangkan $R^{2}=0,306$ dengan $p<0,01$. Menunjukkan bahwa semakin negatif konsep diri dan semakin rendah kecerdasan emosional yang dimiliki oleh para pendeta semakin tinggi srtes kerja yang dimilikinya. Hasil tersebut sesuai dengan yang dikemukakan oleh Bachman (dalam Stein, 2003) keterkaitan konsep kesadaran akan diri dengan kecerdasan emosional memungkinkan individu memiliki sikap yang mandiri, tidak ragu-ragu untuk mengungkapkan kemampuan dengan efektif, mampu bekerja mencapai sasaran dengan cara mengelola waktu, mengolah informasi, dan meningkatkan kemampuan berkomunikasi dan bernegosiasi, serta memiliki optimis dan kebahagiaan, yang menciptakan suasana hati yang stabil sehingga individu dapat mengatasi stres, penolakan, frustasi, dan kekecewaan dalam pekerjaan. Dengan demikian konsep diri yang negatif dan kecerdasan emosional yang rendah akan sangat berpengaruh terhadap peningkatan atau penurunan stres kerja pendeta. Dimana konsep kesadaran akan diri dengan kecerdasan emosional memungkinkan individu menerima diri sendiri dan perasaannya sehingga individu memiliki sikap yang mandiri, optimis dan mampu mengatasi stres, penolakan, frustasi, dan kekecewaan dalam pekerjaannya. Hasil ini juga sejalan dengan teori yang dikemukakan Collins (1989) bahwa faktor pemicu stres adalah isolasi dari masyarakat, tuntutan yang berlebihan, masalah administrasi, masalah 
keuangan, dan tekanan mental (dari diri sendiri). Ini sering sekali berdampak pada pendeta dan keluarganya sering sekali merasa gagal dan bersalah besar apabila mereka tidak dapat menjadi model seperti yang diinginkan oleh jemaatnya. Kemudian masalah kemarahan, setiap individu bisa marah dan marah tidak selalu buruk. Tetapi kemarahan seringkali menyebabkan luapan emosi yang tidak terkendali, kata-kata yang kasar, menyakitkan, kritik dan rusaknya hubungan dengan sesama.

\section{SIMPULAN}

Berdasarkan hasil analisis statistik yang telah dilakukan dalam penelitian ini, maka dapat dikemukakan beberapa kesimpulan, yaitu: Ada hubungan negatif yang sangat signifikan antara konsep diri dengan stres kerja pada pendeta GBKP di wilayah Langkat yang ditunjukkan oleh $r_{x 1 y}=-0,335$ dengan $p=0,004$. Arah hubungan yang negatif (tanda negatif pada angka 0,335) menunjukkan bahwa semakin negatif konsep diri akan akan membuat stres kerja semakin tinggi. Angka $\mathrm{R}^{2}$ sebesar 0,112 berarti konsep diri memiliki kontribusi sebesar 11,2 \% dalam menjelaskan stres kerja. Sementara sisanya dipengaruhi oleh variabel lain.

Ada hubungan negatif yang signifikan antara kecerdasan emosional dengan stres kerja di pada pendeta GBKP di wilayah Langkat yang ditunjukkan oleh koefisien $r_{x 2 y}=-$ 0,527 dengan $p=0,000$. Arah hubungan yang negatif (tanda negatif pada angka 0,527 ) menunjukkan bahwa semakin rendah kecerdasan emosional akan akan membuat stres kerja semakin tinggi. Angka $\mathrm{R}^{2}$ sebesar 0,278 berarti kecerdasan emosional memiliki kontribusi sebesar 27,8 \% dalam menjelaskan stres kerja. Sementara sisanya dipengaruhi oleh variabel lain.

Ada hubungan negatif yang signifikan antara konsep diri dan kecerdasan emosional dengan stres kerja pada pendeta GBKP di wilayah Langkat yang ditunjukkan oleh koefisien $\mathrm{F}=$ Freg $=8,605 ; \mathrm{R}=0,553$ dengan $\mathrm{p}=0$,01. Artinya secara bersama-sama konsep diri yang negatif dan rendahnya kecerdasan emosi yang dimiliki pendeta menyebabkan tingginya stres kerja yang dimilikinya. Angka $\mathrm{R}^{2}$ sebesar 0,306 berarti variabel konsep diri dan variabel kecerdasan emosional memberikan kontribusi sebesar 30,6 \% dalam menjelaskan stres kerja, sisanya dipengaruhi oleh variabel lain.

\section{DAFTAR PUSTAKA}

Agus, A.R. (2014). Psikologi Sosial Integrasi Pengetahuan Wahyu dan Pengetahuan Empirik. Jakarta: PT Raja Grafindo Persada

Anoraga, P, (2009). Psikologi Kerja. Jakarta: PT Rineka Cipta

Arikunto, S, (2013). Prosedur Penelitian Suatu Pendekatan Praktik. Jakarta: Rineka Cipta

Azwar, S, (2007). Penyusunan Skala Psikologi. Yogyakarta: Pustaka Pelajar

Azwar, S, (2009). Reliabilitas dan Validitas.Yogyakarta: Pustaka Pelajar

Chandra, R.I., (2003). Ketika Aku Dipanggil Melayani-Nya. Jakarta: Binawarga

Colbert, D. (2008). Emosi Yang Mematikan. Jakarta: Imanuel Publishing House

Collins, G.R., (1989). Konseling Kristen Yang Efektif. Malang: Seminari Alkitab Asia Tenggara

Darmaputera, E. (2005). Gereja Harus Bertumbuh. Yogyakarta: Penerbit Kairos

Fabella, A. T., (1993). Sanggup Mengatasi Stress. Jakarta: Indonesia Pubblishing House Ofset

GBKP, Moderamen, (2015). Tata Gereja GBKP 2015-2025. Kabanjahe: Moderamen GBKP

Gintings, E.P., (2002). Gembala dan Penggembalaan. Kabanjahe: Abdi Karya

Gintings, E.P., (2006). Pendeta Dipimpin dan Dipakai Oleh Roh Kudus. Medan: PGI SUMUT

Goleman, D, (2016). Emotional, Kecerdasan Emosional; Mengapa EI lebih penting dari IQ. Jakarta: PT Gramedia Pustaka Utama 
Hamdani, R., Lahmuddin L., Aziz, A., (2015), Hubungan antara Dukungan Sosial dan Kecerdasan Emosional dengan Self-Regulated Learning Siswa. Analitika: 7 (2): 105-117

Harahap, E.R., Ferry N., Gustiarti L., (2014), Peranan Kohesivitas Kelompok Dan Kecerdasan Emosional Terhadap Organizational Citizenship Behavior, Analitika: 6 (1): 1-10

Hartono \& Soedarmadji, Boy, (2014). Psikologi Konseling Edisi Revisi. Jakarta: Kencana Prenada Media Group

Hidayat, D.R., (2011). Teori Dan Aplikasi Psikologi Kepribadian Dalam Konseling. Penerbit Ghalia Indonesia (Anggota IKAPI)

Koeswara, E., (1988). Agresi Manusia. Bandung: PT Aresco

Luthans, F, (2006). Perilaku Organisasi. Yogyakarta: Penerbit Andi

Nainggolan, W.S.. Chandra, A., \& Sembiring, S.A. (2017). Hubungan Dukungan Sosial dengan Harga Diri pada Mantan Pengguna Narkoba, Jurnal Diversita, 3 (2): 94-100

Patton, P, (1998). Emotional Intelligence Di Tempat Kerja. Jakarta: PT Pustaka Delapratasa

Poerwardanaminta, W.J.S., (1988). Kamus Besar Bahasa Indonesia. Jakarta: Balai Pustaka

Puspasari, A, (2009). Emotional Intelligent Parenting: Mengukur Emotional Intelligence Anak dan Membentuk Pola Asuh Berdasarkan Emotional Intelligent Parenting. Jakarta: PT Elex Media Komputindo

Ruben, A, (2014). Konsep Diri. Langkat: CV. Mitra

Semium, Y., (2013). Teori-Teori Kepribadian Psikoanalitik Kontemporer Jilid 1. Yogyakarta: Kanisius

Simanjuntak, J, (2014). Pendeta Panggilan, Kepribadian, dan Keluarganya. Tangerang: Pelikan Indonesia

Siregar, N. (2018). Kualitas Hidup Wanita Menopause Ditinjau dari Dukungan Sosial di Kelurahan Sempakata $\begin{array}{llll}\text { Padang Bulan Medan. JURNAL DIVERSITA, } & 4(1), \quad \text { 9-15. }\end{array}$ doi:https://doi.org/10.31289/diversita.v4i1.1566

Siregar, N.I., Sri E., (2012) Hubungan Konsep Diri dan Kecerdasan Emosi dengan Motivasi Belajar, Analitika: 4 (1): $38-42$

Stein, S. J., \& E.Book, Howard, (2003). Ledakan EQ: 15 Prinsip Dasar Kecerdasan Emosional Meraih Sukses. Bandung: Kaifa

Strauch, A, (1992). Manakah Yang Alkitabiah Kepenatuaan atau Kependetaan, Yogyakarta: Yayasan Andi

Sunyoto M.. (2001). Psikologi Industri Dan Organisasi. Jakarta: Universitas Indonesia

Suryabrata, S, (2005). Alat Ukur Psikologis. Yogyakarta: C.V Andi Offset

Suryabrata, S, (2007). Psikologi Kepribadian. Jakarta: PT Raja Grafindo Persada

Syarifah, \& Nefi D., (2010), Pengaruh Locus Of Control dan Kecerdasan Emosional terhadap Kemampuan Memecahkan Masalah pada Remaja Desa Percut Kecamatan Percut Sei Tuan, Analitika: 2 (2): 88-98

Tarigan, M. (2018). Hubungan Dukungan Sosial dengan Subjective Well-Being pada Remaja yang Memiliki Orangtua Tunggal. JURNAL DIVERSITA, 4(1), 1-8. doi:https://doi.org/10.31289/diversita.v4i1.1565

Tyson, S \& Jackson, T, (2000). The Essence Of Organizational Behaviour: Perilaku Organisasi. Yogyakarta: Penerbit Andi

Wade, C. dan Tavris, C, (2007). Psikologi Jilid 2. Jakarta: Erlangga

Walz, E, (2001). Bagaimana Mengelola Gereja Anda. Jakarta: PT BPK Gunung Mulia

Winarti, E, (2003). Pengembangan Kepribadian. Jakarta: Fajar LP3i

Wipperman, J, (2007). Meningkatkan Kecerdasan Emosional. Jakarta: Prestasi Pustaka

Wongso, P, (2002). Theologia Penggembalaan. Malang: Departemen Literatur SAAT

Zuraida, Kaiman T, \& Sri S, (2015), Hubungan Kecerdasan Emosional dan Dukungan Sosial Keluarga dengan Burnout, Analitika: 7 (2): 141-149 